\title{
The Role of Technology in the Aesthetics of Postwar Serial Music
}

Marcus Zagorski / marcus.zagorski@uniba.sk

Department of Musicology, Faculty of Arts, Comenius University in Bratislava, SK

\begin{abstract}
New ideas about music in Europe around 1950 resulted, in part, from contemporaneous research being done in electroacoustic music studios. Early serial composers, searching for a material untouched by history, turned to the basic components of sound, sound's 'parameters', which were seen as naturally occurring raw materials from which a new music could be built. Ironically, this supposedly natural material could not have been identified without the technology of electroacoustic music studios. Such technology enabled sound events to be analysed-to be literally 'broken up'-into component parts; these components, so-called parameters such as pitch, intensity, duration, and timbre, could then be controlled with rationalized serial methods. This paper examines the significant role research in electroacoustic music studios had in contributing to the aesthetic ideals of postwar serial music.
\end{abstract}

\section{Keywords}

serial music, aesthetics, technology, philosophy of history, parameter, material 
One effective way to begin an examination of the aesthetics of postwar serial music is to begin by considering the material of music. What is the material of music? According to Aristotle, who, in his Physics, was the first to give a thorough philosophical definition of the concept, material is "that from which something comes to be." When this definition is applied to music, it soon becomes apparent that there are many different things from which different musics come to be. The material of electroacoustic music, for example, may be very different from the material of a 19th-century symphony. While the latter might utilize a number of harmonies or pitches arranged into scales of intervallic relations, the former might make use of pre-recorded sounds from an urban environment or sounds generated by computers. In light of this fact, it can be more insightful to make a historical study of how different people have defined musical material at different times, rather than give a general definition of musical material. Such an approach can be more insightful not only because it recognizes that different musics are informed by different aesthetic assumptions, but also because it can tell us much about the aesthetic assumptions behind specific definitions of material. A case in point can be found in a radio lecture delivered in 1963 by the composer Gottfried Michael Koenig: the definition of musical material he gave in this lecture reveals essential aspects of both the aethetics of postwar serial music and the role of technology in this music.

In his radio lecture, Koenig claimed that the development of serialism in the early 1950s was "the moment of birth of what we today call musical material." ${ }^{1}$ His point was not that the concept of musical material was born with serialism; rather, his point was that a shared understanding of material (shared among serial composers, at least) was born with serialism, and the purpose of his lecture was to outline the features of that shared understanding. According to Koenig:

"Musical material is spoken of a lot today [in 1963]. This term is understood to refer to the so-called 'parameters'-or those properties that can be analyzed from a musical event: individual pitches, intensities, durations, timbres [...] The idea that one can present certain musical strata in a kind of 'pure culture' underlies the talk about musical material." ${ }^{2}$

Musical material is identified here explicitly as the parameters of a musical event, the "individual pitches, intensities, durations, [and] timbres." As we will see, these parameters were thought to be the basic components of sound, and were found in music through

$1 *$ I am grateful for the financial support of VEGA-Slovakia Research Agency grants 1/0086/15 and $1 / 0637 / 15$. A broader examination of the some of the ideas presented in this essay can be found in: ZAGORSKI, Marcus. Material and History in the Aesthetics of "serielle Musik". Journal of the Royal Musical Association, 2009, vol. 134, no. 2, p. 271-317.

"Das war gewissermaßen die Geburtsstunde dessen, was wir heute musikalisches Material nennen." KOENIG, Gottfried Michael. Das musikalsiche Material - Ein Begriff und seine Fragwürdigkeit. Ästhetische Praxis. Texte zur Musik 2. Saarbrücken, 1992, 143-153, here p. 149. The program was originally broadcast on Bayerischer Rundfunk München. Translations are my own unless otherwise noted.

2 "Es wird heute viel vom musikalischen Material gesprochen. Man stellt sich darunter beispielweise die sogenannten 'Parameter' vor, also diejenigen Eigenschaften, in die sich ein musikalisches Ereignis zerlegen läßt: einzelne Tonhöhen, Lautstärken, Tondauern, Klangfarben Die Rede vom musikalischen Material liegt die Vorstellung zugrunde, man könne gewisse Schichten der Musik sozusagen in Reinkultur darstellen.” Ibid., p. 143. 
work done in electroacoustic studios. Such work, Koenig noted, was associated with a culture of purity, for purity was said to reside in basic musical elements untouched by historical associations. By returning to these elements of sound, composers attempted to lay the foundations for a new theory and practice, and, ultimately, for a new music that represented their historical moment shortly after World War II.

This moment, in which Koenig claimed serialism was "discovered" (rather than invented), and in which the concept of musical material was "formulated with its greatest [...] urgency," was said by him to be exemplified in Pierre Boulez's first book of Structures. ${ }^{3}$ So it should not surprise us that in Boulez's essay "Schoenberg is Dead," written at about the same time as his Structures, Boulez himself identified the same parameters described by Koenig. Boulez referred to these as the "four constituents of sound" to which the serial principle should be applied if history were to move forward after Schoenberg's death. He suggested, "perhaps we might generalize the serial principle to the four constituents of sound: pitch, duration, [intensity], and timbre [...] Perhaps we might [...] investigate [...] the attempt [of] generating structure from [this] material." ${ }^{\prime}$ If Boulez did not yet use the word "parameter," he did point to the four elements that engaged the interest of those working in electroacoustic music studios at that time, and he referred to them explicitly as his " $m a$ terial". This material would acquire the name "parameter" in the following year.

The term "parameter" was first identified as part of geometry in the mid 18th-century encyclopedias of Zedler and Diderot. The term appeared in theoretical writings on serial music in 1953, very soon after these writings themselves first appeared. ${ }^{5}$ Its application to serial music was due primarily to Karlheinz Stockhausen, who first used the term in his "Arbeitsbericht 1952/53" to describe his composition Kontra-Punkte. ${ }^{6}$ Stockhausen's use of the term followed from his contact with Werner Meyer-Eppler, a professor at the Institute for Phonetics and Communications Studies in Bonn and leading researcher in electronic music, whom he first met in 1952 and would later study with at that university. ${ }^{7}$ This collaboration between Stockhausen and Meyer-Eppler highlights the significant role research in electroacoustic music studios had for early serial music-a significance that cannot be overstated: early serialism is inseparable from electronic composition. ${ }^{8}$

This mutual dependence helps explain why the first issue of the journal die Reihe was dedicated to electronic music. The subtitle of die Reihe, Information über serielle Musik, names the journal as the official mouthpiece of serialism, and the first issue, entitled

3 Ibid., p. 152.

4 BOULEZ, Pierre. Schoenberg is Dead. Stocktakings from an Apprenticeship, trans. Stephen Walsh. Oxford, 1991, 2019-214, here p. 214.

5 BLUMRÖDER, Christoph von. Parameter. In Terminologie der Musik im 20. Jahrhundert (Handwörterbuch der musikalischen Terminologie, Sonderband I), ed. Hans Heinrich Eggebrecht. Stuttgart: Franz Steiner Verlag, 1995, pp. 333-340, here p. 333.

6 Ibid., p. 335.

7 Ibid., p. 335.

8 According to Grant, "serialism can hardly be understood without taking into account its relationship to electronic composition: the one not only had a decisive impact upon the other, but electronic music encapsulates many of the most important aspects of serialism." GRANT, Morag J. Serial Music, Serial Aesthetics: Compositional Theory in Postwar Europe. Cambridge: Cambridge University Press, 2001, 50. 
Elektronische Musik, contained essays by Stockhausen, Meyer-Eppler, Boulez, and Koenig, among others. ${ }^{9}$ By 1955, the year the issue was published, the term "parameter" had been taken up by many composers and theorists to become a standard part of the vocabulary, ${ }^{10}$ and the term's prevalence prompted one historian to state unequivocally that "the concept of the parameter [was] the most important music-theoretical concept of the 1950s." 11 Because the terms "parameter" and "material" were often used as synonyms, it could be said that the concept of material was equally important, and this is indeed why Koenig's radio lecture on serialism stressed the importance of the concept of material.

In subsequent issues of die Reihe, the concept of the "parameter" was expanded to parallel an expanding conception of serialism, which was no longer applied only to the organization of basic components such as pitch, intensity, duration, and timbre, but also associated with the global structuring of harmony, polyphony, tempo, and register. ${ }^{12}$ The expanded conception of parameter (and musical material) was essential to the historical narrative of serialism. As composers explored new aspects of sound and subjected these to rationalized ordering, they saw themselves pushing history forward, with new material providing physical evidence of new stages of progress. This tendency was noted by Koenig in his radio lecture: with respect to material, he stated that "in the beginning, one's attention was focused on pitches, durations, intensities, and timbres"; but shortly thereafter interest shifted to other materials such as new performance techniques and new types of sound. Although this historical progress was said to follow an objective plan, it was of course really an expression of subjective compositional choices-even if no one at the time acknowledged them as such.

Such a picture of history was held by many composers influenced by serialism in the postwar period. It is evident in a brief historical sketch provided by György Ligeti in an essay, written for die Reihe in 1960, on developments in musical form:

"After Schoenberg had found a rule-based method for ordering free atonality, the serial principle, which was first applied only to the dimension of pitch, strove for expansion to the totality of form. This led to the discrete quantification of all parameters [...] accordingly, musical structure assumed the 'pointillistic' character. But only shortly after durations, intensities, and timbres had been serially organized, the expansion of this method sought to cover more global categories, such as relationships between [different] registers and densities, distributions of types of movement and structure, as well as the proportioning of the entire course of form [...] This again changed the state of form considerably: 'pointillistic' form enlarged to 'statistic-field governed' form." 13

9 See die Reihe: Information über serielle Musik, 1955, vol. 1, which was edited by Herbert Eimert and Stockhausen.

10 BLUMRÖDER, op. cit., 335.

11 "Der Begriff des Parameters ist der wichtigste musiktheoretische Begriff der fünfziger Jahre; wenigstens ist seither kein wichtigerer aufgetreten." Ulrich Siegele, "Entwurf einer Musikgeschichte der sechziger Jahre," quoted in ibid., p. 336.

12 Ibid., p. 337.

13 "Die solcherart installierte chromatische Republik bedurfte aber ihrer eigenen gesetzlichen Ordnung. Nachdem Schönberg sie gefunden hatte, strebte das zunächst nur für die Dimension der Tonhöhen aufgestellte serielle Prinzip zur Ausbreitung auf die Totalität der Form. Dies leitete zu jener diskreten Quantifizierung aller Parameter, durch die solche 
The changes Ligeti outlined in prose are better appreciated in conjunction with musical examples that represent the stages in his idea of historical progress. Ex. 1 gives the prime form of Schoenberg's first completely twelve-tone composition, the Suite for piano, opus 25, along with the opening bars of its fourth movement, the Intermezzo.

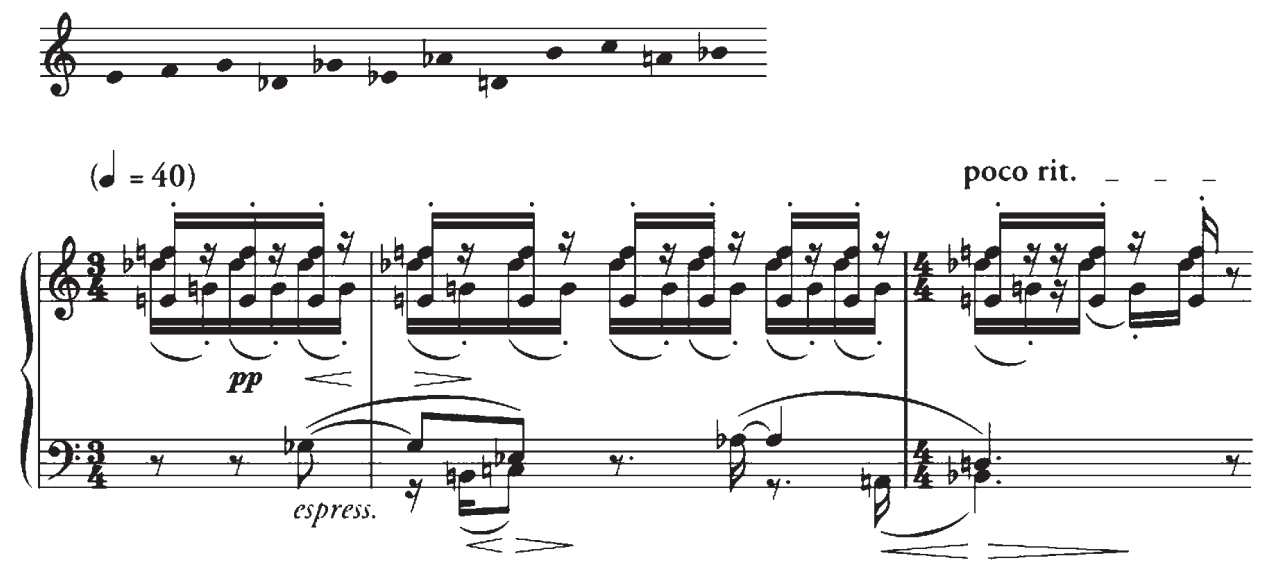

Ex. 1 Arnold Schoenberg, Suite, opus 25, prime form (P-0); mm. 1-3 of the Intermezzo

The spatial layout of these opening bars is clearly modeled on tonal music, and Schoenberg has taken great care to distinguish the individual parts that comprise the texture. The background, repetitive accompaniment figure in the right hand is made of two parts differentiated by articulation and pitch placement: the vertical minor ninth $\left(e^{1}-f^{2}\right)$, stemmed upward, is staccato throughout, while the horizontal, descending diminished fifth $\left(\mathrm{d}-\mathrm{flat}{ }^{2}-\mathrm{g}^{1}\right)$, stemmed downward, is bound by a slur followed by staccato. In contrast to this, the foreground, primary voices, labeled espressivo, that comprise the duet in the left hand have individual dynamic profiles; these parts are further distinguished from the accompaniment by their metrical placement and legato articulation. Schoenberg used pitch to reinforce the coherence of the whole: the twelve-tone set is divided into three tetrachords, the first of which is repeated in the two parts of the accompaniment, while the second and third unfold respectively in the upper and lower voices of the duet. A ritenuto brings the musical idea to a close.

\footnotetext{
Musik zum Produkt aus Überschneidungen präfabrizierter Anordnungen wurde; so nahm die musikalische Struktur den Charakter des 'Punktuellen' an. Kaum waren jedoch Zeitdauern, Intensitätsgrade und Klangfarben seriell organisiert, suchte die Expansion dieser Methode globalere Kategorien zu umfassen, wie Register- und Dichteverhältnisse, Verteilungen von Bewegungs- und Strukturtypen, zugleich auch Proportionierung des gesamten Formablaufes. Damit entstanden aber beträchtliche Verschiebungen in der kompositorischen Planung: mit serieller Steuerung umfassender Formkategorien lockerte sich Schritt für Schritt die Einordnung der elementaren Parameter; ihre strenge Festsetzung wurde eher zweitrangig für die Gesamtkomposition; dies wiederum verändert den Habitus der Form erheblich: das 'Punktuelle' erweiterte sich zum 'Statistisch-Feldmäßigen'." LIGETI, György. Wandlungen der musikalischen Form. die Reihe, 1960, vol. 7, pp. 5-17, here p. 5.
} 
Schoenberg wrote that he developed his new technique as a rule-based method for ordering free atonality (Ligeti referred to it the same way), and in the essay "Composition with Twelve Tones" Schoenberg described the new method as a necessary historical development dictated by the laws of nature.$^{14} \mathrm{He}$ therefore made an appeal to an objective truth beyond his own subjective compositional decisions. Ligeti made the same claim, stating that the serial principle "strove for expansion to the totality of form," which led to the "discrete quantification of all parameters" which I have given as Ex. 2.

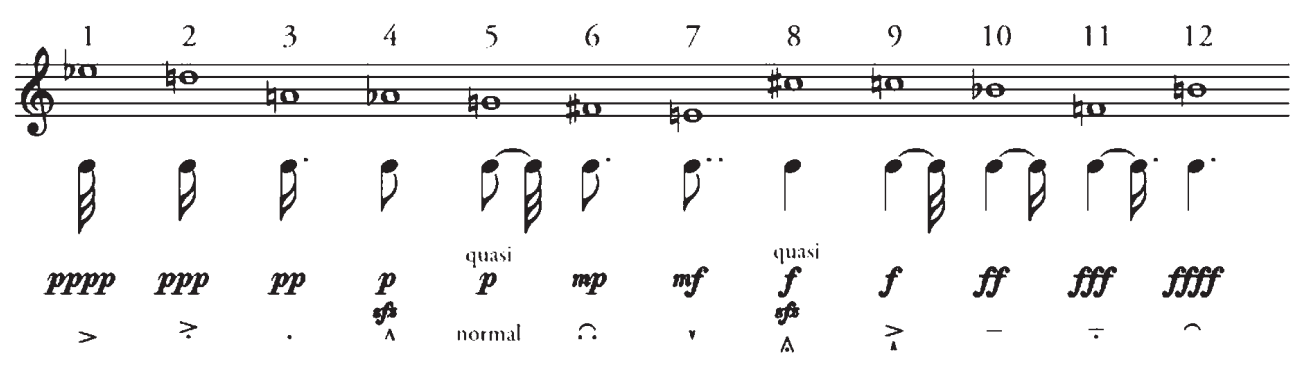

Ex. 2 Pierre Boulez, Structure la, series in prime form

Ex. 2 is so well known and overused that I am almost embarrassed to show it again. But perhaps my essay will help you see it in a different context. Here the prime form of the series used in Boulez's Structure Ia shows the serial principle applied also to duration, intensity, and timbre; along with pitch, these other series were used to generate the music. At the time he composed the piece, Boulez believed such an expansion of the serial principle followed from the pitch material he used and was, he thought, a logical consequence of history-just as Schoenberg thought the 12-tone method was a logical consequence of history. ${ }^{15}$ The opening bars of the resulting composition are shown in Ex. 3.

Perhaps most striking, when compared with the Schoenberg example, is the difference in the textural conception of the music-that is, the layout of musical space: the Boulez example has no clear hierarchy of parts, no distinction between the primary and subsidiary, between melody and accompaniment. To speak of melody and accompaniment at all seems misguided, for the texture is characterized by a scattering of "points" across sound-space. The purposefully static musical environment of these seven bars is created by the lack of registral focus, the lack of any sense of meter, and the unchanging loudness and articulation within each instrument-and it is a consequence of the new understanding of material that was said by Koenig to be born with serialism.

14 Additional analytical comments on Schoenberg's Suite for Piano, opus 25, and a discussion of the genesis of the twelve-tone method appear in MORGAN, Robert P. Twentieth-Century Music: A History of Musical Style in Modern Europe and America. New York: W. W. Norton, 1991, 187-200. See also SCHOENBERG, Arnold. Composition with Twelve Tones. Style and Idea, ed. Leonard Stein, trans. Leo Black. Berkeley: University of California Press, 1975, pp. 241-226.

15 See BOULEZ, op. cit., pp. 209-214. 

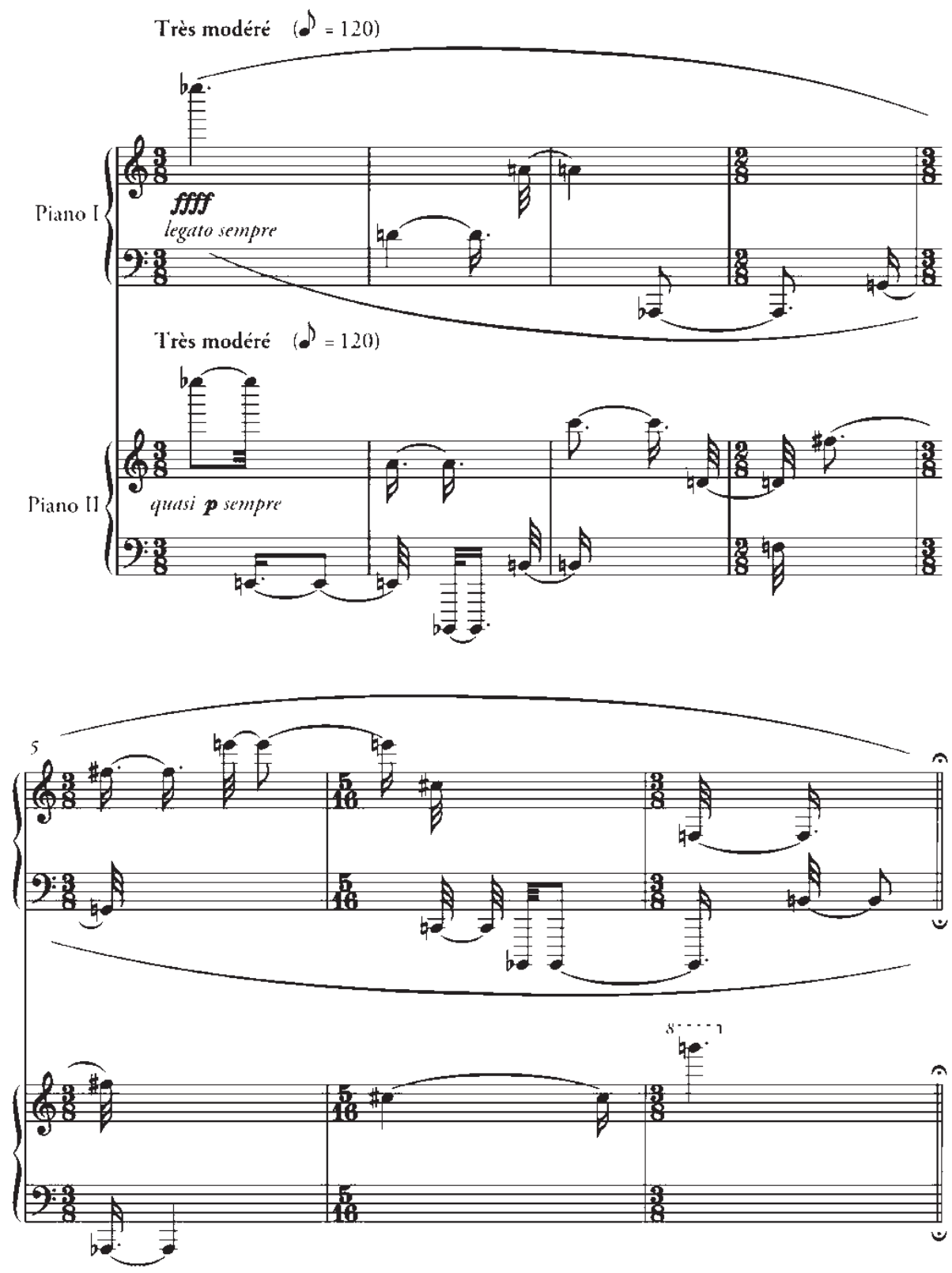

Ex. 3 Pierre Boulez, Structure la, mm. 1-7

The final form mentioned by Ligeti resulted from a further expansion of serial organization, which he said "sought to cover more global categories" such that "pointillistic" form enlarged to "statistic-field governed" form. Stockhausen used what he called "statistical" or "collective" form in pieces composed in the mid-1950s such as Gesang der Jünglinge, 
Gruppen, and Zeitmaße. Such forms were characterized by shifts between textures in which individual elements disappear within a larger sound-complex, and textures in which individual elements emerge and can be perceived as independent-shifts, in other words, between groups and points (in contrast to the mere points of "pointillistic" music). ${ }^{16}$ Ex. 4 presents an excerpt from Zeitmaße for five woodwinds in which, beginning at bar 29, individual instruments break away from the global tempo they had in common and adopt their own individual tempi. According to Stockhausen (who liked to imitate scientific language), the instruments thereby create a sound-complex in which "statistical criteria" determine the whole due to the complexity of relationships between individual parts. ${ }^{17}$

If we return to the quoted passage from Ligeti's essay and look at his historical narrative critically, we can see that he thought that history is not the result of human decisions, but rather an active agency that is guided by a higher purpose: the serial principle, he claimed, strove for expansion to the totality of form; and the expansion of the serial principle then sought to cover more global categories. Much like the "laws of nature" Schoenberg imagined, history functioned for Ligeti as an authority directing the the development and expansion of serial music. The categories from and to which the serial principle was expanded-from basic parameters such as pitch, duration, intensity, and timbre to more global categories related to the development of form-were synonymous with the term "material" in the 1950s. The process of expansion described by Ligeti could be understood, therefore, as the expansion of material, and this narrative underpinned the historical, aesthetic, and technical esprit-or better yet, the rather more Hegelian Geist-of serial and post-serial music.

Koenig, too, was tuned-in to the progress of the historical Geist. And like so many since Hegel, he described it as a necessary truth rather than a convenient lie invented by humans. What he did critique, however, was the notion of "purity" that was attached to the new conception of musical material. He claimed that after the Second World War, composers turned to this material in the belief that it was pure and uncorrupted. As to the question of what had not corrupted it, he stated, "there is only one answer: specific musical works, [that is] history." ${ }^{18}$ As early serial composers sought musical materials uncorrupted by the residue of the past, they turned to the basic components of sound: sound's "parameters," which were seen as a naturally occurring materia prima-raw materials from which a new world could be built.

16 For this conception of "statistical form" see STOCKHAUSEN, Karlheinz. Erfindung und Entdeckung: Ein Beitrag zur Form-Genese. Texte 1: Zur elektronischen und instrumentalen Musik, ed. Dieter Schnebel. Cologne: DuMont, 1963, 222-237. For a more comprehensive examination of Stockhausen's use of the word "statistic" see DECROUPET, Pascal. Stockhausen: Statistik und Form, 1957. In Im Zenit der Moderne: Die Internationalen Ferienkurse für neue Musik Darmstadt 1946-1966, vol. 2, ed. Gianmario Borio and Hermann Danuser. Freiburg: Rombach, 1997, pp. 219-223.

17 STOCKHAUSEN, op. cit., p. 235.

18 "Nichtsdestoweniger ist der Begriff des musikalischen Materials von Reinheit und Unberührtheit erfüllt. Auf die Frage, wovon es nicht berührt sei, gibt es nur eine Antwort: von spezifischen Werken, von Geschichte." KOENIG, op. cit., p. 143. 


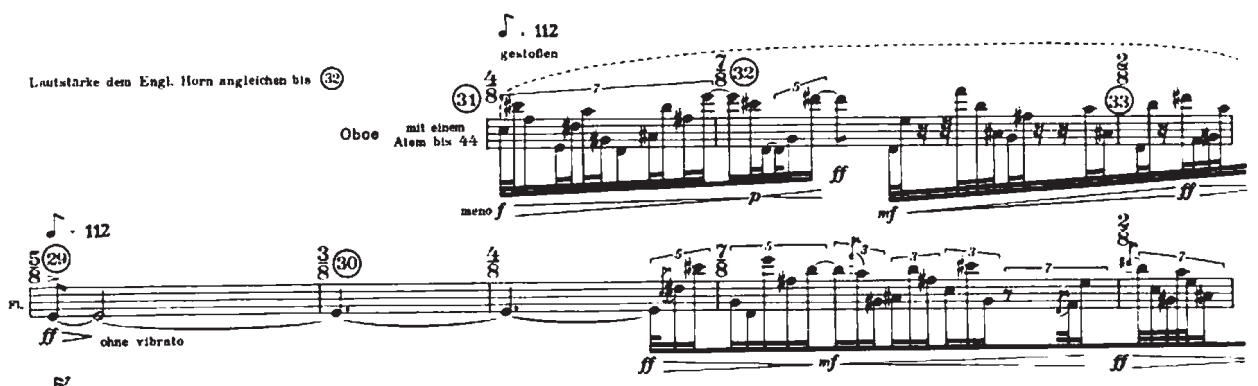

E. so stinell wie moglich
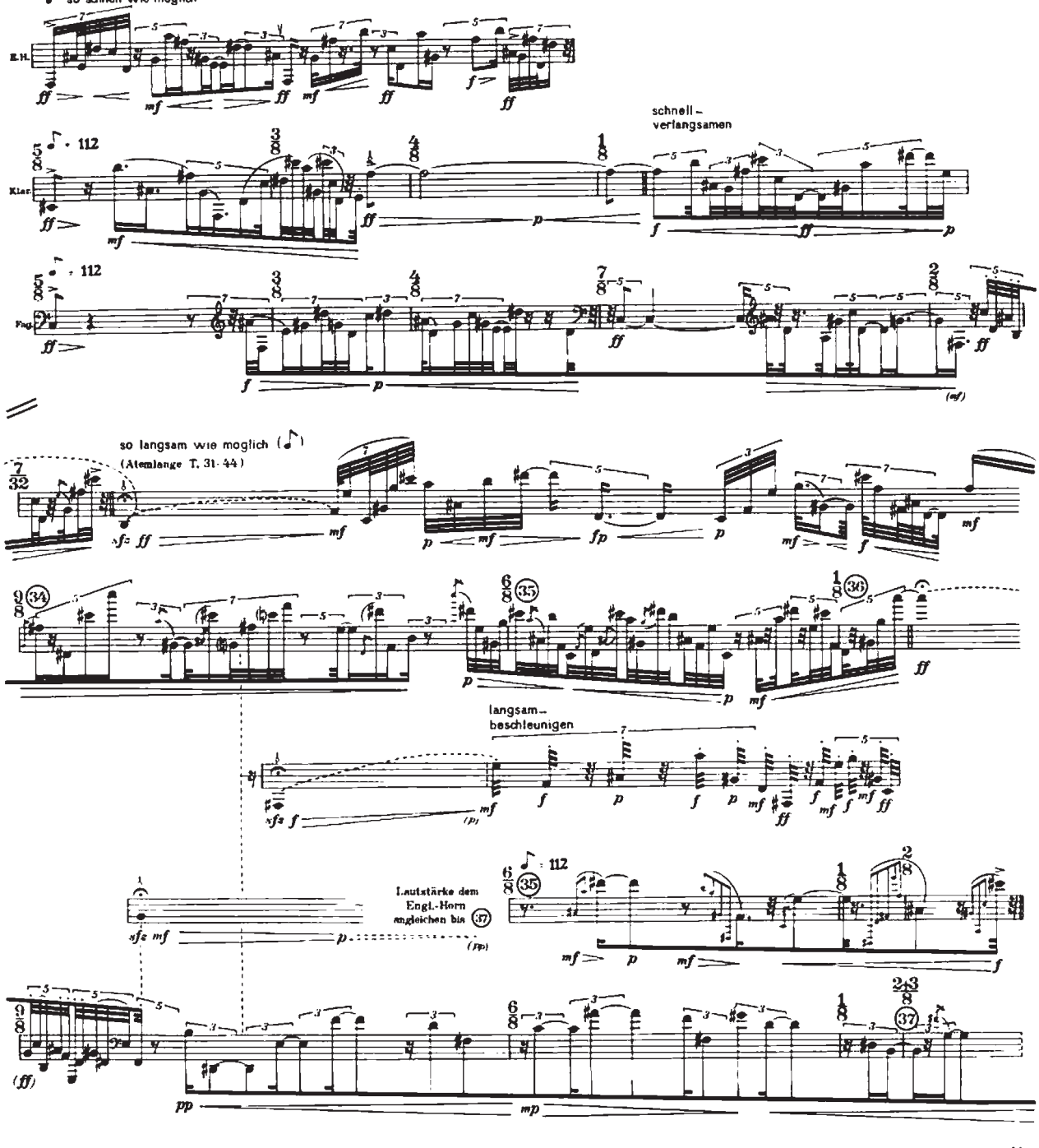

บะ $12607 \mathrm{LW}$

Ex. 4 Karlheinz Stockhausen, Zeitmaße, mm. 29-37

(c) Copyright 1957 by Universal Edition (London) Ltd., London/UE 16297 
Paradoxically, this pure, natural material could not have been made without the artificial technology of electronic music studios, and Koenig noted that, "the concept of an entirely pure musical material triumphed in the electronic studio." 19 The technology used in electronic music studios enabled sound events to be analyzed-to be literally "broken up"-into their component parts. And these individual components, such as pitch, intensity, duration, and timbre, could then be controlled and structured precisely: sine tones could be generated at any frequency and broadcast at any amplitude; durations could be measured to the millimeter of the tape upon which the sound was stored; and timbre could be manipulated by altering wave-forms. Particularly in the Cologne studio in the 1950s, where Stockhausen (and Koenig) did extensive work, electronic compositional methods were promoted as a path that would enable the discovery and musical embodiment of sound's natural characteristics. ${ }^{20}$ With the aim of removing the burden of history, research into the "nature" of sound was seen to provide material from which a new music could be made. Shortly after the devastation of World War II, composers created a new future for themselves by means of a music theory in which progress was guaranteed. This progress was said to be founded on "pure" material, which was made from technological discoveries, unsoiled by historical memory, and which shaped the aesthetics of postwar serial music.

\section{Bibliography}

BLUMRÖDER, Christoph von. Parameter. In Terminologie der Musik im 20. Jahrhundert (Handwörterbuch der musikalischen Terminologie, Sonderband I), ed. Hans Heinrich Eggebrecht. Stuttgart: Franz Steiner Verlag, 1995, pp. 333-340.

BOULEZ, Pierre. Schoenberg is Dead. Stocktakings from an Apprenticeship, trans. Stephen Walsh. Oxford: Oxford University Press, 1991, pp. 2019-214.

DAHLHAUS, Carl. Neue Musik und Wissenschaft. In Wissenschaftliche und nichtwissenschaftliche Rationalität: Ein deutsch-französisches Kolloquium, ed. Kurt Hübner and Jules Vuillemin. Stuttgart, 1983, pp. 107-118.

DECROUPET, Pascal. Stockhausen: Statistik und Form, 1957. In Im Zenit der Moderne: Die Internationalen Ferienkurse für neue Musik Darmstadt 1946-1966, vol. 2, ed. Gianmario Borio and Hermann Danuser. Freiburg: Rombach, 1997, pp. 219-223.

die Reihe: Information über serielle Musik, 1955, vol. 1.

GRANT, Morag J. Serial Music, Serial Aesthetics: Compositional Theory in Postwar Europe. Cambridge: Cambridge University Press, 2001.

KOENIG, Gottfried Michael. Das musikalsiche Material - Ein Begriff und seine Fragwürdigkeit. Ästhetische Praxis. Texte zur Musik 2. Saarbrücken, 1992, pp. 143-153.

19 Ibid., p. 145.

20 DAHLHAUS, Carl. Neue Musik und Wissenschaft. In Wissenschaftliche und nichtwissenschaftliche Rationalität: Ein deutsch-französisches Kolloquium, ed. Kurt Hübner and Jules Vuillemin. Stuttgart, 1983, pp. 107-118, here p. 109. 
LIGETI, György. Wandlungen der musikalischen Form. die Reihe, 1960, vol. 7, p. 5-17.

MORGAN, Robert P. Twentieth-Century Music: A History of Musical Style in Modern Europe and America. New York: W. W. Norton, 1991.

SCHOENBERG, Arnold. Composition with Twelve Tones. Style and Idea, ed. Leonard Stein, trans. Leo Black. Berkeley: University of California Press, 1975, pp. 241-226.

STOCKHAUSEN, Karlheinz. Erfindung und Entdeckung: Ein Beitrag zur Form-Genese. Texte 1: Zur elektronischen und instrumentalen Musik, ed. Dieter Schnebel. Cologne: DuMont, 1963, pp. 222-237.

ZAGORSKI, Marcus. Material and History in the Aesthetics of "serielle Musik". Journal of the Royal Musical Association, 2009, vol. 134, no. 2, pp. 271-317. 
